OPEN ACCESS

Edited by:

Guigen Li,

Texas Tech University, United States

Reviewed by:

Dong Liu,

Peking University, China

Jianming Kang,

University of Washington,

United States

Yi-Ning Wang,

Yancheng Institute of

Technology, China

*Correspondence:

Xian-Wen Yang

yangxianwen@tio.org.cn

Specialty section:

This article was submitted to

Organic Chemistry,

a section of the journal

Frontiers in Chemistry

Received: 16 July 2019 Accepted: 07 October 2019 Published: 30 October 2019

Citation:

Xie C-L, Xia J-M, Lin T, Lin Y-J, Lin Y-K, Xia M-L, Chen H-F, Luo Z-H, Shao Z-Z and Yang X-W (2019) Andrastone A From the

Deep-Sea-Derived Fungus Penicillium allii-sativi Acts as an Inducer of Caspase and RXR $\alpha$-Dependent Apoptosis. Front. Chem. 7:692. doi: 10.3389/fchem.2019.00692

\section{Andrastone A From the Deep-Sea-Derived Fungus Penicillium allii-sativi Acts as an Inducer of Caspase and $\mathbf{R X R} \alpha$-Dependent Apoptosis}

\author{
Chun-Lan Xie ${ }^{1,2}$, Jin-Mei Xia ${ }^{1}$, Ting Lin ${ }^{2}$, Ying-Jie Lin ${ }^{1}$, Yu-Kun Lin ${ }^{1}$, Man-Li Xia ${ }^{1}$, \\ Hai-Feng Chen ${ }^{2}$, Zhu-Hua Luo ${ }^{1}$, Zong-Ze Shao ${ }^{1}$ and Xian-Wen Yang ${ }^{1 *}$ \\ ${ }^{1}$ Key Laboratory of Marine Biogenetic Resources, Third Institute of Oceanography, Ministry of Natural Resources, Xiamen, \\ China, ${ }^{2}$ School of Pharmaceutical Sciences, Xiamen University, Xiamen, China
}

Two new (1, 2) and one known (3) meroterpenoids were isolated from the deep-sea-derived fungus Penicillium allii-sativi. The relative structures of new compounds were determined on the basis of an extensive analysis of the NMR and MS data, and the absolute configurations were established by ECD calculations. Andrastone A (1) is a rare andrastin bearing an unusual cyclopentan-1,3-dione. It shows a selectively antiproliferative effect against HepG2 tumor cells with an $\mathrm{IC}_{50}$ value of $7.8 \mu \mathrm{M}$. Mechanism study showed that apoptosis via Caspase and $\mathrm{RXR} \alpha$ pathways are responsible for the inhibitory effect.

Keywords: deep-sea, meroterpenoids, microorganisms, anti-tumor, nuclear receptors

\section{INTRODUCTION}

The ocean yields an impressive array of novel compounds with exquisite structures and potent bioactivities (Blunt et al., 2017, 2018). Interestingly, more and more evidence shows that marine natural compounds are mainly produced by marine microorganisms. In 2017, 57\% of the total new marine natural products were reported from marine microorganisms (Carroll et al., 2019). As our research investigating bioactive secondary metabolites from the deep-sea-derived microorganisms continues, a series of interesting compounds were obtained (Yang et al., 2013; Niu et al., 2017; Xie et al., 2019). The crude extract of Penicillium allii-sativi, a fungus isolated from the deep-sea water of the western Pacific, showed significant antiproliferative activities against several cancer cell lines. Therefore, a chemical investigation was conducted, which led to the discovery of two new and one known meroterpenoids (Figure 1), among which compound $\mathbf{1}$ showed potent effects. Herein, we report the isolation, structure, and bioactivities of these compounds.

\section{MATERIALS AND METHODS}

\section{General Experimental Procedures}

The NMR spectra were recorded on a Bruker $400 \mathrm{MHz}$ spectrometer using TMS as an internal standard. The HRESIMS spectra were measured on a Waters Xevo G2 Q-TOF (Waters) mass spectrometer. Optical rotations were measured with an Anton Paar MCP100 polarimeter. CD spectra were measured on a JASCO J-715 spectropolarimeter. The semipreparative HPLC was 


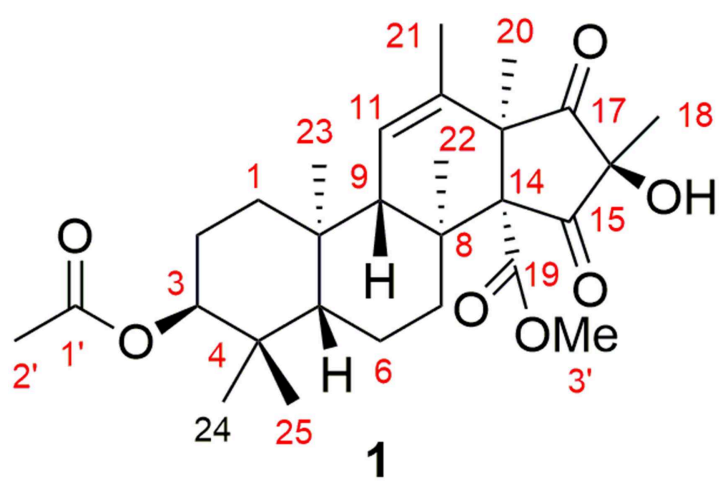

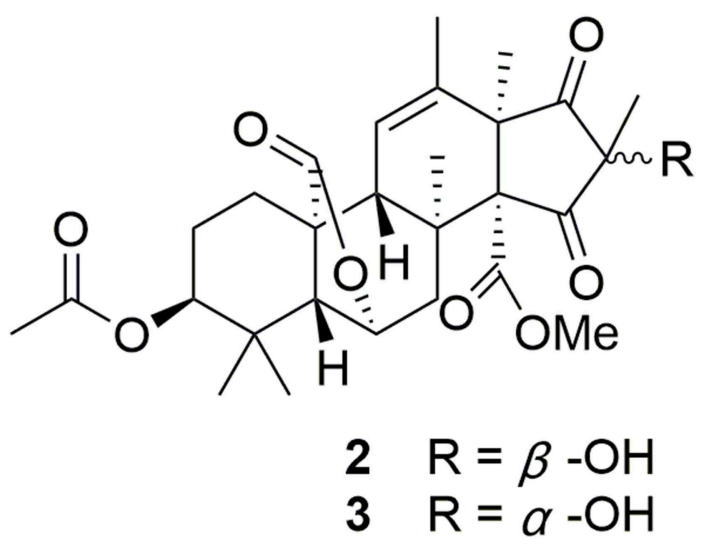

FIGURE 1 | Chemical structures for compounds 1-3.

carried out on an Agilent technologies 1260 infinity instrument equipped with DAD detector (Agilent, USA) using a reversedphase C18 column $(5 \mu \mathrm{m}, 10 \times 250 \mathrm{~mm}$; Cosmosil, Japan). Column chromatography (CC) was performed on silica gel, Sephadex LH-20 (Amersham Pharmacia Biotech AB), and ODS (50 $\mu \mathrm{m}$, Daiso, Japan).

\section{Fermentation, Extraction, and Isolation}

Penicillium allii-sativi was isolated from the deep-sea water of the western Pacific at a depth of $-4,302 \mathrm{~m}$, in 2012. The voucher strain is preserved at the Marine Culture Collection of China (Xiamen, China) with the accession number of MCCC 3A00580.

The fungus was cultured on a PDA plate at $25^{\circ} \mathrm{C}$ for 3 days. The fresh mycelia were then cultured in $50 \times 1 \mathrm{~L}$ Erlenmeyer flasks under static conditions at $28^{\circ} \mathrm{C}$, each containing $80 \mathrm{~g}$ rice and $120 \mathrm{~mL}$ distilled water. After 30 days, the fermented broth was extracted with EtOAc for three times. The organic solvent was evaporated under reduced pressure to afford an organic extract $(120 \mathrm{~g})$. The extract was partitioned by $\mathrm{MeOH}$ and then extracted with petroleum ether (PE). The $\mathrm{MeOH}$ layer was concentrated to provide a defatted extract $(60.4 \mathrm{~g})$.

The extract was subjected to $\mathrm{CC}$ on silica gel eluted with gradient $\mathrm{CH}_{2} \mathrm{Cl}_{2}-\mathrm{MeOH}$ to get 8 fractions (Fr.1-Fr.8). Fractions Fr.3 (5.5 g) was $\mathrm{CC}$ over ODS using a gradient $\mathrm{H}_{2} \mathrm{O}-\mathrm{MeOH}$, followed by CC on silica gel (PE-acetone, 5:1) to give $\mathbf{1}(5.0 \mathrm{mg}$ ). The other fraction Fr.5 (6.7 g) was subsequently subjected to CC over ODS and Sephadex LH-20 (MeOH). Final purification by preparative $\mathrm{HPLC}$ using $\mathrm{H}_{2} \mathrm{O}-\mathrm{MeOH}(20 \rightarrow 80 \%)$ provided $2(3.5 \mathrm{mg})$, and by preparative TLC $\left(\mathrm{CH}_{2} \mathrm{Cl}_{2}-\mathrm{MeOH}, 10: 1\right)$ afforded 3 (4.3 $\mathrm{mg}$ ), respectively.

Andrastone A (1): colorless oil; $[\alpha]_{\mathrm{D}}^{20} 0.32$ (c 0.50, $\left.\mathrm{CHCl}_{3}\right)$; $\left.[\alpha]_{\mathrm{D}}^{20}-7.2(c) 0.50, \mathrm{MeOH}\right) ; \mathrm{UV}(\mathrm{MeOH}) \lambda \max (\log \varepsilon)$ 206 (3.34) nm; CD (MeOH) $\Delta \varepsilon_{214}+0.48, \Delta \varepsilon_{231}-0.08$, $\Delta \varepsilon_{260}+1.36, \Delta \varepsilon_{315}-2.03 ;{ }^{1} \mathrm{H}$ and ${ }^{13} \mathrm{C} \mathrm{NMR}$ data (see Table 1), HRESIMS $m / z 511.2672[\mathrm{M}+\mathrm{Na}]^{+}$(calcd for $\left.\mathrm{C}_{28} \mathrm{H}_{40} \mathrm{O}_{7} \mathrm{Na}, 511.2666\right)$.

16-epi-Citreohybriddione A (2): colorless oil; $[\alpha]_{\mathrm{D}}^{20}-166.3$ (c 1.0, $\mathrm{CHCl}_{3}$ ); UV (MeOH) $\lambda \max (\log \varepsilon) 205$ (4.06) nm; CD
$(\mathrm{MeOH}) \Delta \varepsilon_{215}+5.55, \Delta \varepsilon_{222}+2.67, \Delta \varepsilon_{254}+14.18, \Delta \varepsilon_{310}$ -36.39; ${ }^{1} \mathrm{H}$ and ${ }^{13} \mathrm{C}$ NMR data (see Table 1); HRESIMS $m / z$ $539.2257[\mathrm{M}+\mathrm{Na}]^{+}$(calcd for $\mathrm{C}_{28} \mathrm{H}_{36} \mathrm{O}_{9} \mathrm{Na}, 539.2252$ ). Citreohybriddione $A(3)$ : non-merohedral twin crystal; $[\alpha]_{\mathrm{D}}^{20}$ -134.5 (c 0.3, MeOH); ${ }^{1} \mathrm{H}$ and ${ }^{13} \mathrm{C}$ NMR data (see Table 1); HRESIMS $m / z 539.2260[\mathrm{M}+\mathrm{Na}]^{+}\left(\right.$calcd for $\mathrm{C}_{28} \mathrm{H}_{36} \mathrm{O}_{9} \mathrm{Na}$, 539. 2259).

\section{X-Ray Crystallographic Analysis of Compound 3}

Compound 3 was obtained as a colorless non-merohedral twin crystal. The crystal data were recorded with an Xcalibur Eos Gemini single-crystal diffractometer with $\mathrm{Cu} \mathrm{K} \alpha$ radiation $(\lambda=$

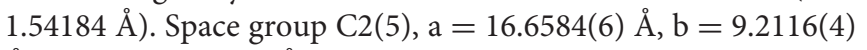
$\AA, \mathrm{c}=18.8507(10) \AA, \alpha=90^{\circ}, \beta=109.545^{\circ}, \gamma=90^{\circ}, \mathrm{V}=$ $2725.97 \AA^{3}, \mathrm{Z}=4, \mathrm{D}_{\text {calcd }}=1.259 \mathrm{~g} / \mathrm{cm}^{3} ; \mu=0.830 \mathrm{~mm}^{-1}, \mathrm{~F}$ $(000)=1,154$; The final $\mathrm{R}$ indices $[\mathrm{I}>2 \operatorname{sigma}(\mathrm{I})] R_{1}=0.0691$, $\mathrm{w} R_{2}=0.2044$. The absolute structure parameter was 0.2 (2). Crystallographic data of 3 have been deposited in the Cambridge Crystallographic Data Center, with deposition number CCDC 1936654. Copies of the data can be obtained, free of charge, on application to CCDC, 12 Union Road, Cambridge CB21EZ, U.K. [fax +44(0)-1233-336033; email: deposit@ccdc.cam.ac.uk].

\section{Anti-proliferative Assay}

Cytotoxic activities of all three compounds were conducted on seven human cancer cell lines of HepG2, A549, BIU-87, BEL-7402, ECA-109, Hela-S3, and PANC-1 by MTT method as reported previously (Yang et al., 2008).

\section{Apoptosis Determination}

After treated with $1(5 \mu \mathrm{M})$ for $24 \mathrm{~h}$, HepG2 cells were stained with $5 \mu \mathrm{L}$ propidium iodide (PI) by adding $5 \mu \mathrm{L}$ Annexin VAPC, in darkness for $15 \mathrm{~min}$. The apoptosis results were analyzed using a FAC scan flow cytometer (Becton Dickinson, Sparks, Maryland, USA), as described previously (Xie et al., 2019). Paclitaxel was used as the positive control. 
TABLE 1 | ${ }^{1} \mathrm{H}\left(400 \mathrm{MHz}\right.$ ) and ${ }^{13} \mathrm{C}(100 \mathrm{MHz})$ NMR spectroscopic data of compounds 1-3 ( $\delta$ in ppm, $\mathrm{J}$ in $\mathrm{Hz}$ within the parenthesis).

\begin{tabular}{|c|c|c|c|c|c|c|c|c|}
\hline \multirow[t]{2}{*}{ No } & \multicolumn{2}{|r|}{$1^{a}$} & \multicolumn{2}{|r|}{$2^{b}$} & \multicolumn{2}{|r|}{$2^{c}$} & \multicolumn{2}{|r|}{$3^{b}$} \\
\hline & $\delta_{\mathrm{C}}$ & $\delta_{\mathrm{H}}$ & $\delta_{\mathrm{C}}$ & $\delta_{\mathrm{H}}$ & $\delta_{\mathrm{C}}$ & $\delta_{H}$ & $\delta_{\mathrm{C}}$ & $\delta_{\mathrm{H}}$ \\
\hline 1 & 32.6, $\mathrm{CH}_{2}$ & $\begin{array}{l}\text { 1.55, m } \\
0.99, \mathrm{dt}(13.4,2.7)\end{array}$ & $21.8, \mathrm{CH}_{2}$ & $\begin{array}{l}2.10(\mathrm{dd}, 14.0,3.2) \\
1.43, \mathrm{dd}(14.0,5.8)\end{array}$ & $20.8, \mathrm{CH}_{2}$ & $\begin{array}{l}2.13(\mathrm{~d}, 12.4) \\
1.37 \mathrm{~m}\end{array}$ & 22.1, $\mathrm{CH}_{2}$ & $\begin{array}{l}2.16(\mathrm{dd}, 13.9,3.2) \\
1.36 \mathrm{~m}\end{array}$ \\
\hline 2 & $22.2, \mathrm{CH}_{2}$ & $\begin{array}{l}1.93, \mathrm{~m} \\
1.47, \mathrm{~m}\end{array}$ & 23.1, $\mathrm{CH}_{2}$ & $\begin{array}{l}1.75, \mathrm{~m} \\
1.66 \mathrm{dd}(13.9,3.4)\end{array}$ & 22.0, $\mathrm{CH}_{2}$ & $1.73 \mathrm{~m}$ & 22.9, $\mathrm{CH}_{2}$ & $\begin{array}{l}1.77, \mathrm{~m} \\
1.67(\mathrm{dd}, 15.0,5.0)\end{array}$ \\
\hline 3 & $76.8, \mathrm{CH}$ & $4.55, \mathrm{t}(2.5)$ & $77.3, \mathrm{CH}$ & 4.62, br s & $75.9, \mathrm{CH}$ & 4.63 br s & $77.3, \mathrm{CH}$ & $4.64, d(1.8)$ \\
\hline 4 & $36.2, \mathrm{C}$ & & $35.5, \mathrm{C}$ & & $34.3, \mathrm{C}$ & & $35.4, \mathrm{C}$ & \\
\hline 5 & $48.8, \mathrm{CH}$ & $1.24, \mathrm{~m}$ & $56.6, \mathrm{CH}$ & $1.94, \mathrm{~s}$ & $55.2, \mathrm{CH}$ & $1.90 \mathrm{~s}$ & $57.0, \mathrm{CH}$ & $1.91, \mathrm{~s}$ \\
\hline 6 & 17.0, $\mathrm{CH}_{2}$ & $1.48, \mathrm{~m}$ & $79.4, \mathrm{CH}$ & $4.91, d(4.0)$ & $77.6, \mathrm{CH}$ & $4.77(\mathrm{~d}, 4.0)$ & $79.1, \mathrm{CH}$ & $4.94, d(4.0)$ \\
\hline 7 & 31.3, $\mathrm{CH}_{2}$ & $\begin{array}{l}2.60, \mathrm{dt}(12.8,4.7) \\
2.14, \mathrm{dt}(13.1,2.3)\end{array}$ & $36.3, \mathrm{CH}_{2}$ & $\begin{array}{l}3.07, \mathrm{~d}(14.5) \\
2.65, \mathrm{dd}(13.9,3.4)\end{array}$ & $35.0, \mathrm{CH}_{2}$ & $\begin{array}{l}2.99(d, 14.4) \\
2.69(d d, 14.5,4.3)\end{array}$ & 36.3, $\mathrm{CH}_{2}$ & $\begin{array}{l}3.04, d(14.6) \\
2.70, d d(14.7,4.4)\end{array}$ \\
\hline 8 & $38.9, \mathrm{C}$ & & $40.8, \mathrm{C}$ & & $39.5, \mathrm{C}$ & & 41.1, C & \\
\hline 9 & $52.4, \mathrm{CH}$ & 1.79, t (1.9) & 53.3, $\mathrm{CH}$ & $2.71, \mathrm{t}(2.1)$ & $51.8, \mathrm{CH}$ & $2.59(\mathrm{t}, 2.1)$ & $54.5, \mathrm{CH}$ & $2.42, \mathrm{t}(2.5)$ \\
\hline 10 & $36.6, \mathrm{C}$ & & 45.3, C & & $43.8, \mathrm{C}$ & & $45.0, \mathrm{C}$ & \\
\hline 11 & 127.2, $\mathrm{CH}$ & 5.56 , br s & 125.8, CH & $5.78, \mathrm{br} s$ & 125.3, CH & 5.82 br s & 125.7, CH & 5.86, br s \\
\hline 12 & 131.0, C & & 135.1, C & & 133.6, C & & 137.5, C & \\
\hline 13 & $59.6, \mathrm{C}$ & & $61.9, \mathrm{C}$ & & $61.0, \mathrm{C}$ & & $60.2, \mathrm{C}$ & \\
\hline 14 & $70.8, \mathrm{C}$ & & $74.5, \mathrm{C}$ & & $73.1, \mathrm{C}$ & & 75.1, C & \\
\hline 15 & $211.4, \mathrm{C}$ & & 213.7, C & & 212.1, C & & 215.0, C & \\
\hline 16 & 71.3, C & & 73.0, C & & $71.9, \mathrm{C}$ & & $77.7, \mathrm{C}$ & \\
\hline 17 & 208.3, C & & 209.3, C & & $207.4, \mathrm{C}$ & & $211.9, \mathrm{C}$ & \\
\hline 18 & $20.2, \mathrm{CH}_{3}$ & $1.21, \mathrm{~s}$ & $20.0, \mathrm{CH}_{3}$ & $1.32, \mathrm{~s}$ & $20.1, \mathrm{CH}_{3}$ & $1.37 \mathrm{~s}$ & 25.7, $\mathrm{CH}_{3}$ & $1.40, \mathrm{~s}$ \\
\hline 19 & 167.8, C & & 169.2, C & & $167.4, \mathrm{C}$ & & 168.9, C & \\
\hline 20 & 16.9, $\mathrm{CH}_{3}$ & $1.21, \mathrm{~s}$ & $19.4, \mathrm{CH}_{3}$ & $1.34, \mathrm{~s}$ & $18.5, \mathrm{CH}_{3}$ & $1.34 \mathrm{~s}$ & 19.6, $\mathrm{CH}_{3}$ & $1.36, \mathrm{~s}$ \\
\hline 21 & 18.6, $\mathrm{CH}_{3}$ & 1.60, d (1.1) & $18.8, \mathrm{CH}_{3}$ & $1.71, \mathrm{~s}$ & $18.7, \mathrm{CH}_{3}$ & $1.70 \mathrm{~s}$ & $18.7, \mathrm{CH}_{3}$ & $1.73, \mathrm{~s}$ \\
\hline 22 & $18.2, \mathrm{CH}_{3}$ & $1.18, \mathrm{~s}$ & 21.3, $\mathrm{CH}_{3}$ & $1.40, \mathrm{~s}$ & $20.5, \mathrm{CH}_{3}$ & $1.41 \mathrm{~s}$ & $20.8, \mathrm{CH}_{3}$ & $1.39, \mathrm{~s}$ \\
\hline 23 & $16.5, \mathrm{CH}_{3}$ & $0.84, \mathrm{~s}$ & 181.1, C & & 178.7, C & & 180.6, C & \\
\hline 24 & $21.2, \mathrm{CH}_{3}$ & $0.86, \mathrm{~s}$ & 22.9, $\mathrm{CH}_{3}$ & $0.89, \mathrm{~s}$ & $22.5, \mathrm{CH}_{3}$ & $0.88 \mathrm{~s}$ & $22.5, \mathrm{CH}_{3}$ & $0.88, \mathrm{~s}$ \\
\hline 25 & $27.4, \mathrm{CH}_{3}$ & $0.81, \mathrm{~s}$ & 26.6, $\mathrm{CH}_{3}$ & 0.99, s & 26.3, $\mathrm{CH}_{3}$ & $0.96 \mathrm{~s}$ & $26.5, \mathrm{CH}_{3}$ & $0.99, \mathrm{~s}$ \\
\hline $1^{\prime}$ & 170.0, C & & 172.2, C & & $170.4, \mathrm{C}$ & & 171.8, C & \\
\hline $2^{\prime}$ & $21.1, \mathrm{CH}_{3}$ & $2.03, \mathrm{~s}$ & $20.8, \mathrm{CH}_{3}$ & $2.04, s$ & 21.0, $\mathrm{CH}_{3}$ & $2.02 \mathrm{~s}$ & $20.8, \mathrm{CH}_{3}$ & $2.01, \mathrm{~s}$ \\
\hline $3^{\prime}$ & $51.8, \mathrm{CH}_{3}$ & $3.54, \mathrm{~s}$ & 52.3, $\mathrm{CH}_{3}$ & $3.62, s$ & 52.0, $\mathrm{CH}_{3}$ & $3.62 \mathrm{~s}$ & 52.6, $\mathrm{CH}_{3}$ & $3.61, \mathrm{~s}$ \\
\hline $\mathrm{OH}$ & & $6.37 \mathrm{~s}$ & & & & & & \\
\hline
\end{tabular}

${ }^{a}$ Measure in DMSO- $d_{6}$.

${ }^{b}$ Measure in $\mathrm{CD}_{3} \mathrm{OD}$.

${ }^{c}$ Measure in $\mathrm{CDCl}_{3}$.

\section{Caspase-3, 8, 9 Apoptosis Assays}

HepG2 cells were treated with different concentrations of compound $1(5,10,20 \mu \mathrm{M})$ for $12 \mathrm{~h}$ and caspase activation was investigated using a Caspase-Glo 3/8/9 assay (Promega) following the directions provided by the kit's manufacturer. The resulting luminescence was read using a Multimode plate reader (Envision, Perkin Elmer, USA).

\section{$\mathbf{R X R} \alpha$ Transcriptional Activity}

As reported previously (Duan et al., 2010), the two target plasmids (30 ng pBind RXR $\alpha$ LBD and 60 ng PG5 LUC) were transfected by Liposome 2000 (Invitrogen) in the cell. The cells were then exposed to $\mathbf{1}(10,20,40 \mu \mathrm{M})$ for $16 \mathrm{~h}$. According to the introduction of the Dual-Luciferase Reporter Assay System kit (promega), the activities of Firefly luciferase (FL) and Rellina luciferase (RL) were checked. The fold activities were calculated as the relative luciferase activities ratio between sample and blank control.

\section{RESULTS AND DISCUSSION}

Compound 1 was obtained as colorless oil. The molecular formula of $\mathrm{C}_{28} \mathrm{H}_{40} \mathrm{O}_{7}$ was determined according to the sodium adduct ion peak at $m / z 511.2672[\mathrm{M}+\mathrm{Na}]^{+}$in its HRESIMS spectrum, indicating nine degrees of unsaturation. The ${ }^{1} \mathrm{H}$ and ${ }^{13} \mathrm{C}$ NMR spectra (Supplementary Material) showed 28 carbon signals including eight methyls, one methoxyl, four methylenes, four methines (one olefinic, one oxygenated, and two aliphatic), 
and 11 non-protonated carbons (two ketones, two carboxyls, one olefinic, one oxygenated, and five aliphatic). Except for the typical signals of one methoxyl group $\left[\delta_{\mathrm{H}} 3.54(3 \mathrm{H}, \mathrm{s}) ; \delta_{\mathrm{C}} 51.8\right.$ q] and one acetoxyl moiety $\left[\delta_{\mathrm{H}} 2.03(3 \mathrm{H}, \mathrm{s}) ; \delta_{\mathrm{C}} 21.1 \mathrm{q}, 170.0 \mathrm{~s}\right]$ group, the remaining signals indicated a 25 -carbon skeleton of 1. Since two ketones, two carboxyls, and one olefinic moiety accounted for five degrees of unsaturation, compound $\mathbf{1}$ should be a tetracyclic molecule.

In the COSY spectrum, three fragments were easily deduced according to the correlations of $\mathrm{H}-3 / \mathrm{H}-2 / \mathrm{H}-1, \mathrm{H}-5 / \mathrm{H}-6 / \mathrm{H}-$ 7, and $\mathrm{H}-9 / \mathrm{H}-11 / \mathrm{H}-21$. In the $\mathrm{HMBC}$ spectrum, the longrange cross peaks originated from $\mathrm{Me}-18, \mathrm{Me}-20$, and $\mathrm{Me}-22-$ Me-25 established a tetracyclic skeleton of 1. Further HMBC correlations of H-3 and H-3' to the carboxyl groups at $\delta_{\mathrm{C}} 170.0$ and 167.8 confirmed the attachment of the acetoxyl and methoxyl at C-3 and C-19, respectively. Accordingly, the planar structure of $\mathbf{1}$ was established as shown in Figure 2.

The relative configuration of $\mathbf{1}$ was assigned mainly by the NOESY spectrum. Correlations were found of $\mathrm{H}-5$ to $\mathrm{H}-9 / \mathrm{Me}-$ $25 / \mathrm{H}-7 \mathrm{a}\left(\delta_{\mathrm{H}} 2.60, \mathrm{td}, J=12.8,4.7 \mathrm{~Hz}\right), \mathrm{H}-9$ to $16-\mathrm{OH}\left(\delta_{\mathrm{H}} 6.37\right.$, s), Me-25 to $3-\mathrm{OAc} / \mathrm{H}-2 \mathrm{a}\left(\delta_{\mathrm{H}} 1.47 \mathrm{~m}\right), \mathrm{H}-2 \mathrm{~b}\left(\delta_{\mathrm{H}} 1.93 \mathrm{~m}\right)$ to Me$24, \mathrm{H}-7 \mathrm{~b}\left(\delta_{\mathrm{H}} 2.14\right.$, td, $\left.J=13.1,2.3 \mathrm{~Hz}\right)$ to $\mathrm{Me}-22 / \mathrm{Me}-23 / 3^{\prime}-\mathrm{OMe}$. Therefore, $\mathrm{H}-5 / \mathrm{H}-9 / \mathrm{Me}-25 / 3-\mathrm{OAc} / 16-\mathrm{OH}$ was supposed to be in the same plane (tentatively assumed as $\beta$-orientation), which is the opposite to $\mathrm{Me}-23 / \mathrm{H}-3 / \mathrm{Me}-24 / \mathrm{Me}-22 / \mathrm{Me}-18$ (regarded as $\alpha$-configuration).

To further assign its absolute stereochemistry, the theoretical calculation of the electronic circular dichroism (ECD) was adopted. As shown in Figure 3, the calculated ECD of $(3 S, 5 S, 8 S, 9 S, 10 R, 13 R, 14 R, 16 R)-1$ (a) showed the same Cotton effects as those of the experimental ones. On the basis of the above evidence, $\mathbf{1}$ was therefore assigned and given the trivial name of Andrastone A.

Compound 2 was also obtained as colorless oil. The molecular formula was established as $\mathrm{C}_{28} \mathrm{H}_{36} \mathrm{O}_{9}$ on the basis of the sodium adduct at $m / z 539.2257[\mathrm{M}+\mathrm{Na}]^{+}$(calcd for $\mathrm{C}_{28} \mathrm{H}_{36} \mathrm{O}_{9} \mathrm{Na}$, 539.2252) in its HRESIMS spectrum. The ${ }^{1} \mathrm{H}$ and ${ }^{13} \mathrm{C}$ NMR spectra showed 28 carbons consisting of seven methyls, one methoxyl, three methylenes, five methines (one olefinic, two oxygenated, and two aliphatic), and 12 non-protonated carbons (two ketones, three carboxyls, one olefinic, one oxygenated, and five aliphatic). These signals were very similar to those of compound 3, a meroterpene that was established as citreohybriddione A by single X-ray crystallography (Figure 4) (Kosemura et al., 1991a). However, clear differences were found in 2 showing that C-16, Me-18 were upshifted up to 4.7 and 5.7 ppm, respectively, suggesting the hydroxy moiety at the C-16 position should be the $\beta$-configuration in 2 , instead of $\alpha$ in 3 . This was confirmed by the NOESY correlations of $3^{\prime}-\mathrm{Me}$ to $\mathrm{Me}-$ 18. By comparison of the experimental and theoretical calculation of the ECD spectra (Figure 3), 2 was therefore assigned to be 16-epi-citreohybriddione A.

Andrastone A (1) and 16-epi-citreohybriddione A (2) are two meroterpenoids biosynthesized from a sesquiterpene and a tetraketide. In fact, compounds possessing the same scaffold

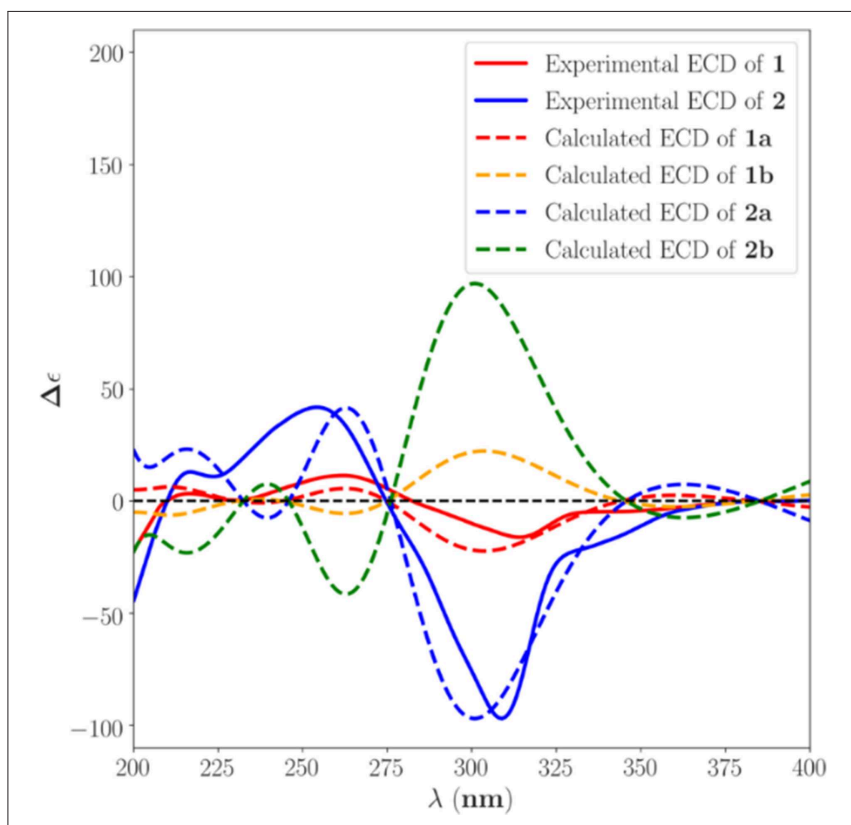

FIGURE $\mathbf{3}$ | Calculated and experimental ECD spectra of $\mathbf{1}$ and $\mathbf{2}$ in $\mathrm{MeOH}$.
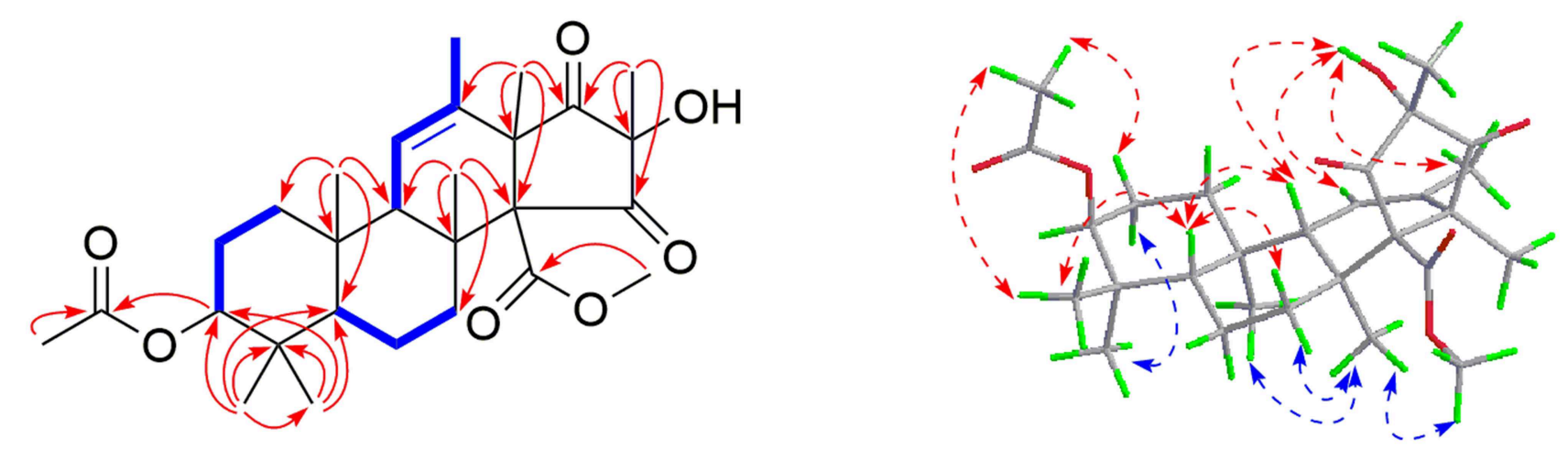

FIGURE 2 | Selected COSY HMBC $(\longrightarrow$, and NOESY $(-\cdots)$ correlations of $\mathbf{1}$ 


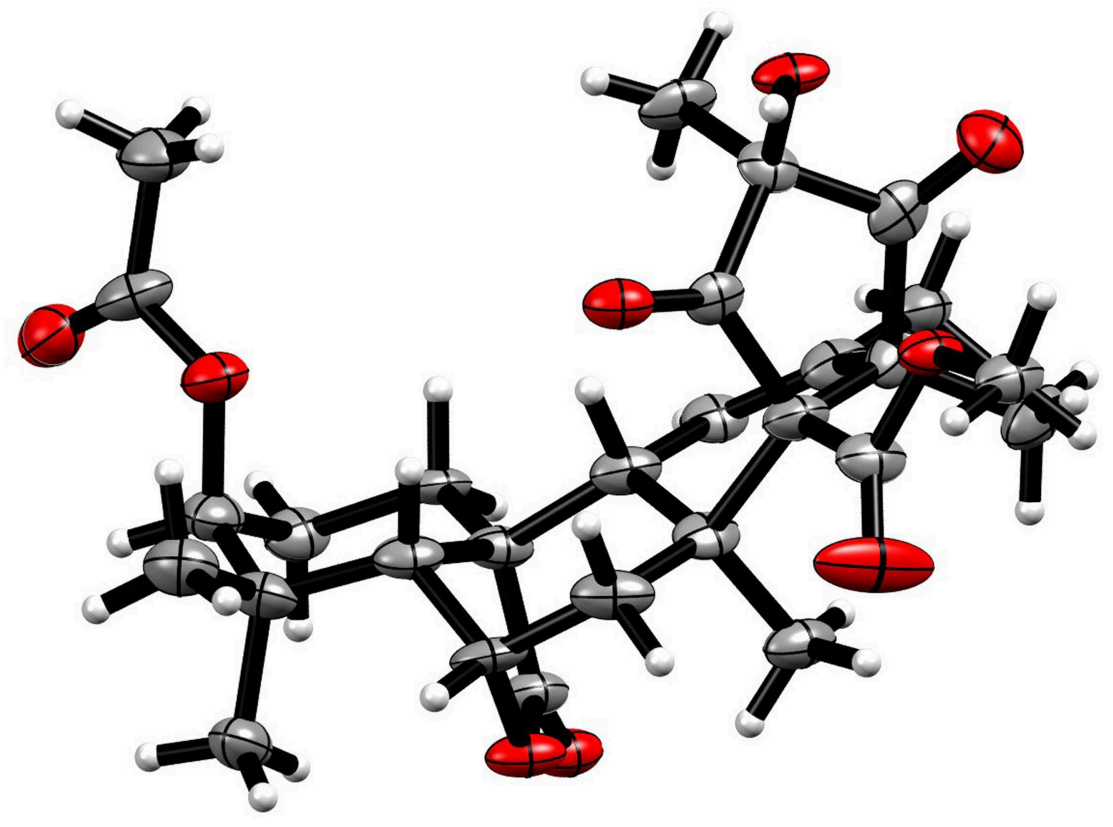

FIGURE 4 | The single X-ray crystallography of 3.

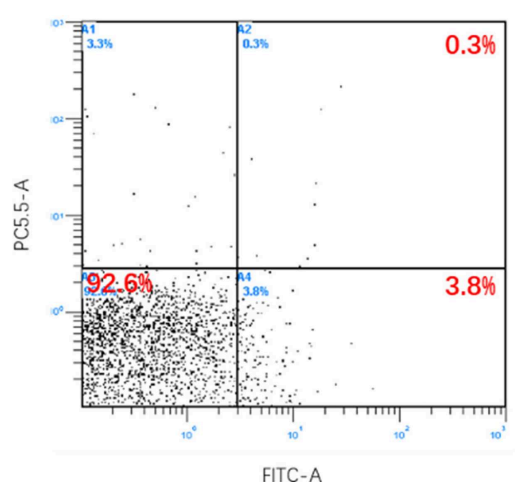

Control

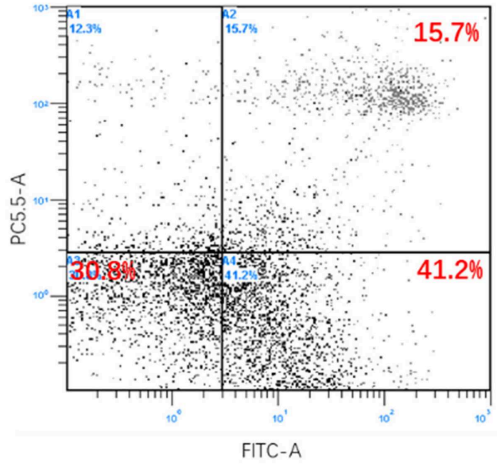

Paclitaxel

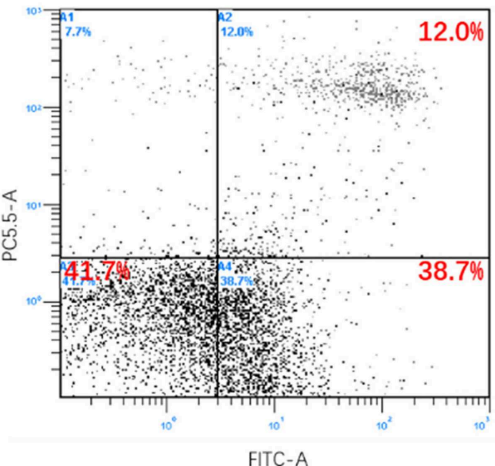

1

FIGURE 5 | Apoptosis effect of $\mathbf{1}$ on HepG2 cells.

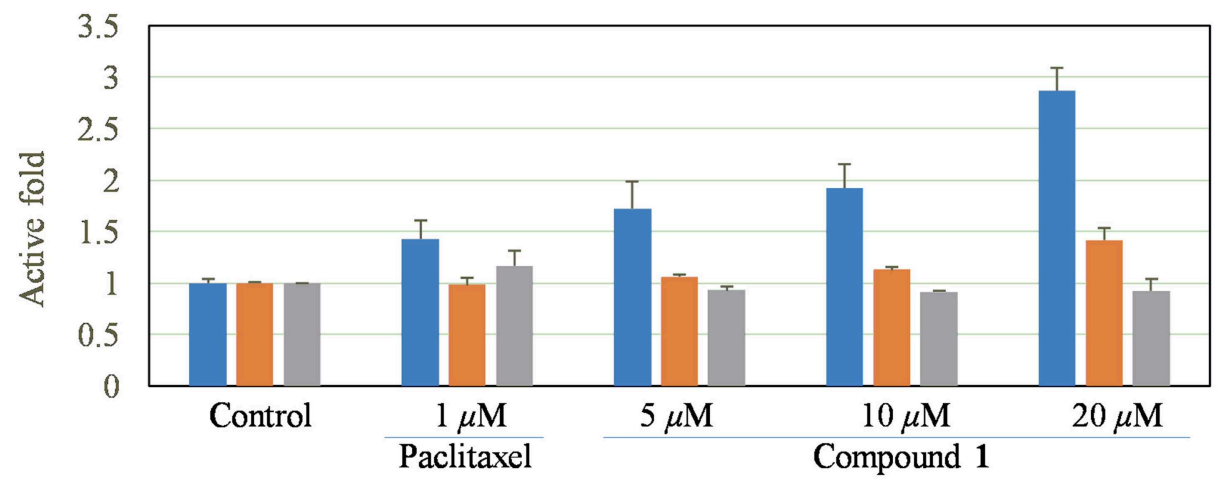

- Caspase 3

- Caspase 8

- Caspase 9

FIGURE 6 | Effect of compound 1 on caspase-3, 8, 9 signaling pathways. 


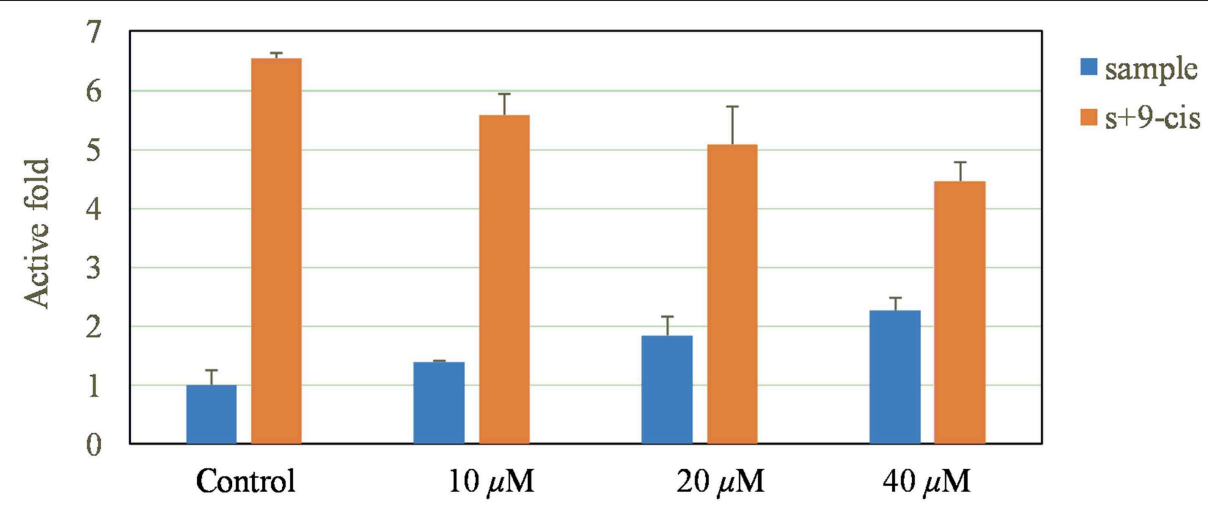

FIGURE 7 | Promoting effect of $\mathbf{1}$ on reporter transcription activities of $\mathrm{RXR} \alpha$.

are rarely found in nature, including citreohybridones $\mathrm{A}$ and $\mathrm{B}$ (Kosemura et al., 1991b), Andrastins A-D (Shiomi et al., 1996; Uchida et al., 1996), atlantinones A and B (Wang et al., 2010), citreohybriddiones A-C (Kosemura, 2003), citreohybridones A-G and J-L (Kosemura, 2002), citreohybridonol (Oezkaya et al., 2018), 3-deacetylcitreohybridonol (Gao et al., 2012), 15-deacetylated citreohybridone E (Cheng et al., 2019), isocitreohybridones A-C and H-J (Kosemura, 2002, 2003), and isopenicins A-C (Tang et al., 2019). Among them, 18 possess a lactone moiety at the $\mathrm{C}-23$ position. For the other 13 compounds, 10 have the keto-enol tautomerism at the cyclopentane ring. Interestingly, compound $\mathbf{1}$ is a rare meroterpene without the lactone moiety but possesses the cyclopentan-1,3-dione group.

Compounds 1-3 were evaluated for their antiproliferative effects against HepG2, A549, BIU-87, BEL-7402, ECA-109, HelaS3, and PANC-1 tumor cells. However, only compound 1 exhibited significant inhibitory activity. Interestingly, it showed a selective effect only on HepG2 cells with an $\mathrm{IC}_{50}$ value of $7.8 \mu \mathrm{M}$. To uncover its inhibition mechanism, 1 was first subjected to flow cytometry. According to a previous study, Paclitaxel can induce apoptosis via arresting cells mainly in the G2/M phase of the cell cycle (Jelinek et al., 2015; Maushagen et al., 2016). Therefore, it was used as the positive control. As shown in Figure 5, Paclitaxel and $\mathbf{1}$ could obviously induce apoptosis in HepG2 cells.

Since caspase is a key pathway to induce apoptosis (Porter and Janicke, 1999; Li and Yuan, 2008), we measured the activities of the caspase-3, 8, and 9. As a result, 1 could significantly increase the activities of caspase- 3 and caspase- 8 , but had almost no effect on caspase-9 (Figure 6), suggesting that the apoptosis was caused by direct caspase-8-mediated caspase- 3 activation (Kaufmann et al., 2008).

Moreover, a dual luciferase reporter gene assay was also carried out to investigate the $\mathrm{RXR} \alpha$ transcriptional activity. Interestingly, 1 not only increased the reporter transcriptional activation of RXR $\alpha$, but also reduced the transactivity of $\operatorname{RXR} \alpha$ induced by 9-cis-RA (Figure 7).

\section{CONCLUSIONS}

In summary, from the deep-sea-derived fungus Penicillium alliisativi, two new and one known meroterpenes were obtained. Andrastone A (1) showed significant inhibitory effect selectively against HepG2 tumor cells by activating caspase- 3 and regulating the transcriptional activation function of $\operatorname{RXR} \alpha$.

\section{DATA AVAILABILITY STATEMENT}

All datasets for this study are included in the manuscript/Supplementary Files.

\section{AUTHOR CONTRIBUTIONS}

C-LX conducted chemical and biological experiments. J-MX, Y-JL, Y-KL, and M-LX assisted C-LX's chemical experiments. TL and H-FC assisted C-LX's bioactive experiments. Z-HL isolated the fungus and Z-ZS deposited it to MCCC. X-WY initiated and oversaw all research.

\section{FUNDING}

This work was financially supported by the Scientific Research Foundation of the Third Institute of Oceanography (2017035), the COMRA program (DY135-B2-08), and the Xiamen Southern Oceanographic Center Project (17GYY026NF05).

\section{ACKNOWLEDGMENTS}

We thank Mr. Tian-Hua Zhong for the measurement of the NMR data.

\section{SUPPLEMENTARY MATERIAL}

The Supplementary Material for this article can be found online at: https://www.frontiersin.org/articles/10.3389/fchem. 2019.00692/full\#supplementary-material 


\section{REFERENCES}

Blunt, J. W., Carroll, A. R., Copp, B. R., Davis, R. A., Keyzers, R. A., and Prinsep, M. R. (2018). Marine natural products. Nat. Prod. Rep. 35, 8-53. doi: $10.1039 / \mathrm{C} 7 \mathrm{NP} 00052 \mathrm{~A}$

Blunt, J. W., Copp, B. R., Keyzers, R. A., Munro, M. H., and Prinsep, M. R. (2017). Marine natural products. Nat. Prod. Rep. 34, 235-294. doi: 10.1039/C6NP00124F

Carroll, A. R., Copp, B. R., Davis, R. A., Keyzers, R. A., and Prinsep, M. R. (2019). Marine natural products. Nat. Prod. Rep. 36, 122-173. doi: 10.1039/C8NP00092A

Cheng, Z., Xu, W., Wang, Y., Bai, S., Liu, L., Luo, Z., et al. (2019). Two new meroterpenoids and two new monoterpenoids from the deep sea-derived fungus Penicillium sp. YPGA11. Fitoterapia 133, 120-124. doi: 10.1016/j.fitote.2018.12.022

Duan, Y. H., Yi, D., Wang, G. H., Xue, Z., Chen, H. F., Chen, J. B., et al. (2010). Bioactive xanthones from the stems of Cratoxylum formosum ssp. pruniflorum. J. Nat. Prod. 73, 1283-1287. doi: 10.1021/np1001797

Gao, S. S., Shang, Z., Li, X. M., Li, C. S., Cui, C. M., and Wang, B. G. (2012). Secondary metabolites produced by solid fermentation of the marine-derived fungus Penicillium commune QSD-17. Biosci. Biotechnol. Biochem. 76, 358-360. doi: 10.1271/bbb.110332

Jelinek, M., Balusikova, K., Schmiedlova, M., Nemcova-Furstova, V., Sramek, J., Stancikova, J., et al. (2015). The role of individual caspases in cell death induction by taxanes in breast cancer cells. Cancer Cell Int. 15, 1-26. doi: 10.1186/s12935-015-0155-7

Kaufmann, S. H., Lee, S. H., Meng, X. W., Loegering, D. A., Kottke, T. J., Henzing, A. J., et al. (2008). Apoptosis-associated caspase activation assays. Methods 44, 262-272. doi: 10.1016/j.ymeth.2007.11.005

Kosemura, S. (2002). Structure and absolute configuration of citreohybridones isolated from Penicillium species. Tetrahedron Lett. 43, 1253-1256. doi: 10.1016/S0040-4039(01)02345-0

Kosemura, S. (2003). Meroterpenoids from Penicillium citreo-viride B. IFO 4692 and 6200 hybrid. Tetrahedron 59, 5055-5072. doi: $10.1016 / S 0040-4020(03) 00739-7$

Kosemura, S., Matsunaga, K., and Yamamura, S. (1991a). Citreohybriddiones A and $\mathrm{B}$ and related terpenoids, new metabolites of a hybrid strain $\mathrm{KO} 0031$ derived from Penicillium citreo-viride B. IFO 6200 and 4692. Chem. Lett. 20, 1811-1814. doi: 10.1246/cl.1991.1811

Kosemura, S., Matsunaga, K., Yamamura, S., Kubota, M., and Ohba, S. (1991b). The structures of citreohybridone A and B novel sesterterpenoid-type metabolites of a hybrid strain KO 0031 derived from Penicillium citreo-viride B. IFO 6200 and 4692. Tetrahedron Lett. 32, 3543-3546. doi: 10.1016/0040-4039(91)80828-T

Li, J., and Yuan, J. (2008). Caspases in apoptosis and beyond. Oncogene 27, 6194-6206. doi: 10.1038/onc.2008.297

Maushagen, R., Reers, S., Pfannerstill, A.-C., Hahlbrock, A., Stauber, R., Rahmanzadeh, R., et al. (2016). Effects of paclitaxel on permanent head and neck squamous cell carcinoma cell lines and identification of anti-apoptotic caspase 9b. J. Cancer Res. Clin. Oncol. 142, 1261-1271. doi: $10.1007 / \mathrm{s} 00432-016-2150-3$
Niu, S., Fan, Z. W., Xie, C. L., Liu, Q., Luo, Z. H., Liu, G., et al. (2017). Spirograterpene A, a tetracyclic spiro-diterpene with a fused 5/5/5/5 ring system from the deep-sea-derived fungus Penicillium granulatum MCCC 3A00475. J. Nat. Prod. 80, 2174-2177. doi: 10.1021/acs.jnatprod.7b 00475

Oezkaya, F. C., Ebrahim, W., Klopotowski, M., Liu, Z., Janiak, C., and Proksch, P. (2018). Isolation and X-ray structure analysis of citreohybridonol from marine-derived Penicillium atrovenetum. Nat. Prod. Res. 32, 840-843. doi: 10.1080/14786419.2017.1311893

Porter, A. G., and Janicke, R. U. (1999). Emerging roles of caspase-3 in apoptosis. Cell Death Differ. 6, 99-104. doi: 10.1038/sj.cdd.4400476

Shiomi, K., Uchida, R., Inokoshi, J., Tanaka, H., Iwai, Y., and Omura, S. (1996). Andrastins A-C, new protein farnesyltransferase inhibitors, produced by Penicillium sp. FO-3929. Tetrahedron Lett. 37, 1265-1268. doi: 10.1016/0040-4039(95)02412-3

Tang, J. W., Kong, L. M., Zu, W. Y., Hu, K., Li, X. N., Yan, B. C., et al. (2019). Isopenicins A-C: Two types of antitumor meroterpenoids from the plant endophytic fungus Penicillium sp. sh18. Org. Lett. 21, 771-775. doi: 10.1021/acs.orglett.8b04020

Uchida, R., Shiomi, K., Inokoshi, J., Tanaka, H., Iwai, Y., and Omura, S. (1996). Andrastin D, novel protein farnesyltransferase inhibitor produced by Penicillium sp. FO-3929. J. Antibiot. 49, 1278-1280. doi: 10.7164 /antibiotics.49.1278

Wang, X. R., Sena Filho, J. G., Hoover, A. R., King, J. B., Ellis, T. K., Powell, D. R., et al. (2010). Chemical epigenetics alters the secondary metabolite composition of guttate excreted by an Atlantic forest soil-derived Penicillium citreonigrum. J. Nat. Prod. 73, 942-948. doi: 10.1021/np100142h

Xie, C. L., Zhang, D., Xia, J. M., Hu, C. C., Lin, T., Lin, Y. K., et al. (2019). Steroids from the deep-sea-derived fungus Penicillium granulatum MCCC 3A00475 induced apoptosis via retinoid X receptor (RXR)- $\alpha$ pathway. Mar. Drugs 17:178. doi: $10.3390 / \mathrm{md} 17030178$

Yang, X. W., Peng, K., Liu, Z., Zhang, G. Y., Li, J., Wang, N., et al. (2013). Strepsesquitriol, a rearranged zizaane-type sesquiterpenoid from the deepsea-derived actinomycete streptomyces sp. SCSIO 10355. J. Nat. Prod. 76, 2360-2363. doi: 10.1021/np400923c

Yang, X. W., Zeng, H. W., Liu, X. H., Li, S. M., Xu, W., Shen, Y. H., et al. (2008). Anti-inflammatory and anti-tumour effects of Abies georgei extracts. J. Pharm. Pharmacol. 60, 937-941. doi: 10.1211/jpp.60.7.0017

Conflict of Interest: The authors declare that the research was conducted in the absence of any commercial or financial relationships that could be construed as a potential conflict of interest.

Copyright () 2019 Xie, Xia, Lin, Lin, Lin, Xia, Chen, Luo, Shao and Yang. This is an open-access article distributed under the terms of the Creative Commons Attribution License (CC BY). The use, distribution or reproduction in other forums is permitted, provided the original author(s) and the copyright owner(s) are credited and that the original publication in this journal is cited, in accordance with accepted academic practice. No use, distribution or reproduction is permitted which does not comply with these terms. 